\title{
The role of mental health to overcoming the coronavirus disease-19 pandemic
}

\author{
Ira Aini Dania ${ }^{1 *}$ and Nanda Novziransyah ${ }^{1}$
}

\begin{tabular}{|c|c|}
\hline ABSTR & $\mathrm{CT}$ \\
\hline $\begin{array}{l}\text { The current coronavirus disease-19 (COVID-19) pandemic has changed } \\
\text { the order of social life; the efforts made to tackle this pandemic have } \\
\text { sometimes raised various obstacles related to norms, ethics and culture. } \\
\text { An increased risk of COVID-19-associated mental disorders is found in } \\
\text { many communities, causing excessive emotional reactions such as feelings } \\
\text { of pressure, leading to unhealthy behavior. This situation confirms that } \\
\text { health care providers have a key role in dealing with emotional disturbances } \\
\text { that occur as a form of pandemic response. Public health emergencies can } \\
\text { affect the health, safety and well-being of every individual as well as the } \\
\text { social stigma in connection with the COVID-19 pandemic. Various mental } \\
\text { health studies related to disasters have determined that emotional distress } \\
\text { is widespread and can also be found in populations related to COVID-19. } \\
\text { There are various kinds of risk factors that have an impact on health workers } \\
\text { during the COVID-19 pandemic, including social isolation, lack of support, } \\
\text { and concerns about safety of family members. We included published, } \\
\text { observational and experimental studies that reported the mental health } \\
\text { effects on health workers during the COVID-19 pandemic. Efforts made by } \\
\text { policy holders, especially in the health sector, have greatly contributed to } \\
\text { the response to the pandemic, but not all of them can run smoothly, several } \\
\text { steps and policies in the health sector must involve many stakeholders in } \\
\text { order to realize the expected efforts. The main purpose of this review paper } \\
\text { was to not only focus on health workers, but include the communities in } \\
\text { overcoming the COVID-19 pandemic. } \\
\text { Keywords: Pandemic, COVID-19, mental health, psychosocial }\end{array}$ & 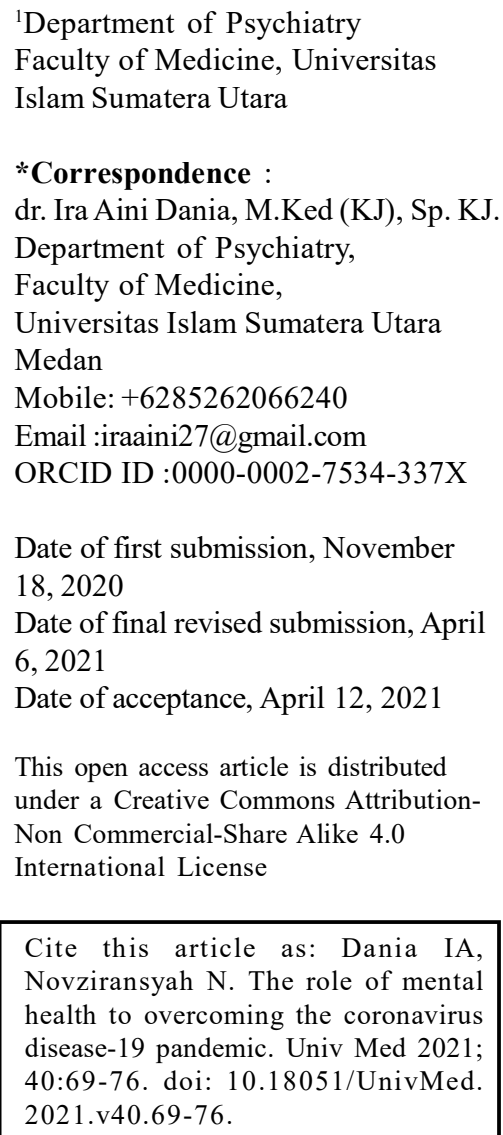 \\
\hline
\end{tabular}




\section{INTRODUCTION}

The current coronavirus disease-19 (COVID-19) pandemic has changed the order of social life and various financial losses have occurred in various sectors, ranging from the health, educational, social, economic sectors and others. ${ }^{(1)}$ Meanwhile, the efforts made to contain this pandemic have sometimes raised various obstacles related to norms, ethics and culture that have been going on and have deep roots. ${ }^{(2)}$ Some of the efforts made by policy holders, especially in the health sector, have greatly contributed to the response to the pandemic. However, not all have been able to run smoothly, since several steps and policies in the health sector are considered in some groups as restricting personal freedom in carrying out activities. ${ }^{(3)}$ Various difficulties and an increased risk of mental disorders associated with Covid19 are found in many communities. ${ }^{(4)}$

\section{Conditions of mental health in the COVID- 19 pandemic}

The above conditions emphasize that health care providers have a very important role and are key persons in dealing with emotional disturbances that occur as a form of pandemic response. Public health emergencies can affect the health, safety and well-being of each individual, causing such reactions as fear, anxiety, insecurity, confusion, emotional isolation and, most importantly, the social stigma in connection with the COVID-19 pandemic. The factors contributing to the burden of emotional distress include economic losses, loss of jobs, problems in the educational sector, resources that are deemed inadequate for medical responses and more uneven distribution of basic needs in society. ${ }^{(5,6)}$ Conditions that can affect medical staff, communities, and families involving Covid-19 pandemic-related situations, could be the causes of excessive emotional reactions such as feelings of pressure that lead to unhealthy behavioral changes such as increased drug use and non-compliance with public health measures such as self-isolation and direct restrictions in social interactions..$^{(7,8)}$

The public health measures carried out on people with confirmed Covid-19, both symptomatic and asymptomatic, create a stigma so that these patients face psychological and social legal conditions of punishment in the community life order, which is not easy for them to deal with. One mental health study in Hongkong involving 500 respondents found that $19 \%$ of the respondents had depression and that $14 \%$ had anxiety related to the Covid-19 pandemic, indicating that emotional distress is widespread and can be found everywhere in the population. ${ }^{(9)}$ In Spain $73 \%$ of the 4180 participants had psychological distress. ${ }^{(10)}$

Health workers, communities, and family members, should be notified that disaster does not make it more meaningful for them to give up under psychological conditions. They should take lessons from all disasters, such as finding new strengths and trying to be more active and resilient in their striving to fulfill their needs both financially and spiritually. ${ }^{(11,12)}$ However, in a "conventional" study of disasters, accidents, and technological and deliberate mass action, the main concern is post-traumatic stress disorder (PTSD) that arises from exposure to trauma. ${ }^{(13,14)}$ Medical conditions from natural causes such as life-threatening viral infections do not meet the current criteria for trauma necessary for the diagnosis of PTSD, but other psychopathology such as depression and anxiety disorders may occur. ${ }^{(15,16)}$ Age groups including the elderly, pregnant women and toddlers as well as those with comorbidities may be more vulnerable than others to the psychosocial effects of the pandemic. ${ }^{(17,18)}$ The age groups that are at high risk of being infected with Covid 19 are especially those in the elderly group, those having a history of chronic diseases such as hypertension, diabetes, heart disease, and people with impaired immune function. ${ }^{(19,20)}$ People living in crowded conditions without possible distancing in social communication, and people with a history of pre-existing medical conditions, 
psychiatric problems, or drug abuse are at high risk of experiencing adverse psychosocial conditions, while adolescents are also prone to experience distress especially when comorbid with other psychiatric disorders. ${ }^{(21,22)}$ Health care providers are also very vulnerable to shocks and emotional changes in the current pandemic, and additionally have a high probability of being exposed to Covid 19 concerns about infection that will impact their families plus the cynical views of people who are considered carriers of the virus. ${ }^{(12,23)}$ The activities of caring for their loved ones, lack of personal protective equipment, working longer hours, and being involved in resource allocation decisions as the vanguard, will of course create emotional reactions. ${ }^{(24)}$ Preventive measures such as screening for mental health problems, psychoeducation, and psychosocial support should focus on other groups at risk for adverse psychosocial conditions such as the inherent stress of the disease itself, advocating for mass isolation or large-scale social restrictions, including messages to stay put in homes, quarantine, and isolation. All of this is new to society, and of course causes a variety of reactions, where each individual will react in conveying his or her concerns, and people will react individually and collectively. ${ }^{(25,26)}$

Several reviews reported the psychological symptoms that were found. A recent review of psychological symptoms in individuals undergoing quarantine includes stress, depression, irritability, insomnia, fear, confusion, anger, frustration, boredom and stigma associated with quarantine, and some of these psychological conditions can persist after quarantine. ${ }^{(27,28)}$ There are many problems that can occur with the existence of large-scale social restrictions and the ongoing quarantine process. Some of the individuals do not have adequate supplies or have difficulties in getting medical care and drugs, which are also experienced by people with severe mental disorders. There are limitations for schizophrenics to get mental health services routinely during this pandemic, whereas ideally the mental health service process should continue even though it only uses telemedicine media based on current technology. ${ }^{(29,30)}$ In patients who are chronically stable and sustain financial losses, this will certainly cause significant psychological stress in groups of people who really subsist without savings, while their basic needs must be met immediately. ${ }^{(31)}$

Six review articles by Kang et al., ${ }^{(32)} \mathrm{Cai}$ et al., ${ }^{(33)}$ Liang et al., ${ }^{(35)}$ Xiao et al., ${ }^{(36)}$ and Mohindra et al. ${ }^{(38)}$ showed that current research focused on assessing several aspects of mental health affected in health care workers due to COVID 19. Several socio-demographic variables, such as gender, profession, age, place of work, department of work and psychological variables, such as poor social support and selfefficacy, were associated with increased stress, anxiety, depressive symptoms, and insomnia in health care workers (Table 1). There is increasing evidence suggesting that COVID 19 can be an independent risk factor for stress in health care workers.

In the current pandemic the risk factors, such as lack of social support, excessive economic burden, occupation, pressure on medical personnel, has not gone unnoticed; the danger will always lurk at the frontline in the tackling of Covid-19. ${ }^{(39)}$ Educational and moral messages echoed through electronic and social media by various parties and policy holders, in this case the government through the Health Service and other related agencies, collaborate with each other to try and break the chain of transmission of Covid-19. All of this never escapes attention, but sometimes there is fake news. ${ }^{(40,41)}$ Confusion about Covid-19 raises various interpretations; some think that Covid19 is not a dangerous viral infection and that recommendations that should be adhered to, such as getting used to washing hands, maintaining social distancing, wearing masks, should be viewed as just ordinary messages that need not be obeyed, because in reality in the field many people who do not comply with these recommendations are doing just fine. ${ }^{(42)}$ 
Table 1. Summary of the studies

\begin{tabular}{|c|c|c|c|c|}
\hline Authors & $\begin{array}{l}\text { Sample including (n) } \\
\text { and place conducted }\end{array}$ & Study design & Instruments used & Main findings \\
\hline $\begin{array}{l}\text { Kang et } \\
\text { al. }{ }^{(32)}\end{array}$ & $\begin{array}{l}994 \text { medical and } \\
\text { nursing staff, Wuhan }\end{array}$ & $\begin{array}{l}\text { Cross- } \\
\text { sectional } \\
\text { study }\end{array}$ & $\begin{array}{l}\text { Patient health } \\
\text { questionnaire-9, } \\
\text { Generalized Anxiety } \\
\text { Disorder, Insomnia } \\
\text { Seventy Index and the } \\
\text { Impact of Event Scale- } \\
\text { Revised }\end{array}$ & $\begin{array}{l}36.9 \% \text { had subthreshold } \\
\text { mental health } \\
\text { disturbances, } 34.4 \% \text { had } \\
\text { mild disturbances, } 22.4 \% \\
\text { had moderate } \\
\text { disturbances, and } 6.2 \% \\
\text { had severe disturbances }\end{array}$ \\
\hline $\begin{array}{l}\text { Cai et al. } \\
\text { (33) }\end{array}$ & $\begin{array}{l}\text { Doctors, nurses, and } \\
\text { other hospital staff (n- } \\
543), \text { Hubei }\end{array}$ & $\begin{array}{l}\text { Cross- } \\
\text { sectional } \\
\text { study }\end{array}$ & $\begin{array}{l}\text { Questionnaire by Lee et } \\
\text { al. }{ }^{(34)}\end{array}$ & $\begin{array}{l}\text { Medical staff experienced } \\
\text { emotional stress during } \\
\text { the COVID-19 outbreak. }\end{array}$ \\
\hline $\begin{array}{l}\text { Liang et } \\
\text { al. }{ }^{(35)}\end{array}$ & $\begin{array}{l}59 \text { doctors and nurses } \\
\text { from COVID-19 } \\
\text { associated department } \\
\text { and others, } \\
\text { Guangdong Province }\end{array}$ & $\begin{array}{l}\text { Cross- } \\
\text { sectional } \\
\text { study }\end{array}$ & $\begin{array}{l}\text { Zung's self-rating } \\
\text { depression scale (SDS), } \\
\text { Zung's self-rating } \\
\text { anxiety scale (SAS). }\end{array}$ & $\begin{array}{l}\text { Several staff were } \\
\text { experiencing clinically } \\
\text { significant depressive } \\
\text { symptoms. }\end{array}$ \\
\hline $\begin{array}{l}\text { Xiao et } \\
\text { al. (36) }\end{array}$ & $\begin{array}{l}180 \text { medical staff } \\
\text { (Doctors or nurses), } \\
\text { China }\end{array}$ & $\begin{array}{l}\text { Cross- } \\
\text { sectional } \\
\text { Observational } \\
\text { Study }\end{array}$ & $\begin{array}{l}\text { Self-Rating Anxiety } \\
\text { Scale, General Self- } \\
\text { Efficacy Scale, Stanford } \\
\text { Acute Stress Reaction } \\
\text { Questionnaire, } \\
\text { Pittsburgh Sleep } \\
\text { Quality Index, and } \\
\text { Social Support Rate } \\
\text { Scale }\end{array}$ & $\begin{array}{l}\text { Levels of social support } \\
\text { were significantly } \\
\text { associated with self } \\
\text { efficacy } \\
\text { and sleep quality and } \\
\text { negatively associated } \\
\text { with the } \\
\text { degree of anxiety and } \\
\text { stress. }\end{array}$ \\
\hline $\begin{array}{l}\text { Lai et al. } \\
\text { (37) }\end{array}$ & $\begin{array}{l}1257 \mathrm{HCW}, \\
20 \text { hospitals in Wuhan, } \\
7 \text { hospitals in other } \\
\text { regions of Hubei } \\
\text { province, } 7 \text { hospitals } \\
\text { from } 7 \\
\text { other provinces }\end{array}$ & $\begin{array}{l}\text { Cross- } \\
\text { sectional } \\
\text { region } \\
\text { stratified } \\
\text { study }\end{array}$ & $\begin{array}{l}\text { Patient Health } \\
\text { Questionnaire-9, } \\
\text { Generalized Anxiety } \\
\text { Disorder scale, } \\
\text { Insomnia Severity } \\
\text { Index, and Impact of } \\
\text { Event Scale-Revised }\end{array}$ & $\begin{array}{l}50.4 \% \text { reported } \\
\text { symptoms of depression, } \\
44.6 \% \text { anxiety, } 34.0 \% \\
\text { insomnia, and } 71.5 \% \\
\text { reported distress }\end{array}$ \\
\hline $\begin{array}{l}\text { Mohindra } \\
\text { et al. } \\
\text { (38) }\end{array}$ & $\begin{array}{l}\text { Frontline health care } \\
\text { providers (HP) } \\
\text { involved in } \\
\text { the care of patients } \\
\text { with COVID-19 or } \\
\text { suspected COVID-19 } \\
\text { Sample size not } \\
\text { specified, tertiary } \\
\text { hospital in } \\
\text { North India }\end{array}$ & $\begin{array}{l}\text { Qualitative } \\
\text { analysis }\end{array}$ & Interviews with HP & $\begin{array}{l}\text { Main themes identified } \\
\text { for mental health } \\
\text { promotion of HP: } \\
\text { 1. Positive: Motivational } \\
\text { factors } \\
\text { a Intellectual } \\
\text { b Emotional } \\
\text { 2. Negative: frustrations } \\
\text { associated with patient } \\
\text { care } \\
\text { 3. Personal fears and } \\
\text { annoyances } \\
\text { experienced by doctors }\end{array}$ \\
\hline
\end{tabular}

Information that is overlapping or different in prevention and management creates confusion for the community so that the impact of psychological pressure is felt by the community. ${ }^{(43)}$ Research conducted in communities severely affected by acute respiratory syndrome (SARS) in the early 2000 s revealed that although community members, affected individuals, and health care workers were motivated to comply with quarantine to reduce the risk of infecting others and to protect public health, the emotional distress of some people was the reason why they considered breaking the rules. ${ }^{(44)}$ 


\section{DISCUSSION}

Crisis management personnel, including health workers, are not themselves immune to the psychological consequences of COVID-19. Health workers facing COVID-19 directly in handling these patients are at greater risk than others. ${ }^{(45)}$ The reasons for the adverse psychological outcomes in health workers range from excessive workload/work hours, inadequate personal protective equipment, overenthusiastic media news, and feelings of being inadequately supported. Here the psychosocial monitoring that is needed to provide support during in-person patient encounters in clinical practice, is severely limited by this crisis. ${ }^{(46)}$ Psychosocial services are delivered via telemedicine, home visits are limited as much as possible, if it is not too emergency, so as not to come to a health service center. In the context of Covid-19, psychosocial assessment and monitoring must be carried out including questions about Covid-19 and related stressors such as exposure to infected sources, infected family members, and physical distance. ${ }^{(47)}$ Other factors include secondary adversity (economic loss, for example), psychosocial effects (such as depression, anxiety, psychosomatics, insomnia, increased drug use, and domestic violence), and indicators of vulnerability (such as preexisting physical or psychological conditions). ${ }^{(35,48)}$

Patients with mental health problems, such as excessive anxiety, mild to severe depression, and acute stress reaction, will need referral for evaluation and formal mental health care, while others may benefit from supportive interventions designed to improve health and coping, such as psychoeducation or cognitive behavioral therapy techniques. ${ }^{(49,50)}$ Because of the economic crisis and a lot of uncertainty surrounding this pandemic, suicidal ideation may arise, which requires immediate consultation with mental health professionals or referral for emergency psychiatric cases. $^{(51,52)}$ The COVID-19 pandemic has changed the basic life order that affects mental health, and various kinds of interventions have been made to reduce emotional distress effectively. ${ }^{(53)}$ The experiences of patients, family members and communities can be normalized by providing the information that the stress experienced during a pandemic is a normal reaction as long as it does not interfere with the function of both individuals and groups. ${ }^{(54,55)}$ One of the supporting efforts is the management of stress management in the midst of dire circumstances. ${ }^{(56)}$

\section{CONCLUSIONS}

Education and training on psychosocial problems is not only for health workers but should be provided to all leaders involved in the health system. Mental health workers and the emergency management community, in this case the COVID-19 Response Acceleration Task Force, must work together to identify, develop and disseminate evidence-based resources related to mental health disasters, mental health triage and referrals, the needs of special populations, and notification of death and treatment in confirmed Covid positive cases. Improvement of mental health includes attempts to reduce or eliminate factors with adverse impacts on mental health along with those related to improving the physical health status.

It is also important to carry out studies for examining the impact of the pandemic-related mental health on healthcare workers. Moreover, it is predicted that implementing the approach for increasing psychological resilience will also protect the mental health of individuals against other risks that may develop.

\section{CONFLICT OF INTEREST}

All authors declare no conflict of interest.

\section{ACKNOWLEDGEMENTS}

We would like to thank the Department of Psychiatry, Faculty of Medicine, Universitas Islam Sumatera Utara. 


\section{CONTRIBUTORS}

IAD and NN conceived idea for this study. NN contributed to interpreting the data. IAD wrote the manuscript and made substantial contributions to the revision of the manuscript. All authors have read and approved the final manuscript.

\section{REFERENCES}

1. Ehrenberg JP, Utzinger J, Fontes G, et al. Efforts to mitigate the economic impact of the COVID-19 pandemic: potential entry points for neglected tropical diseases. Infect Dis Poverty 2021;10: 2 .https://doi.org/10.1186/s40249-020-00790-4.

2. Marazziti D, Pozza A, Di Giuseppe M, Conversano C. The psychosocial impact of COVID-19 pandemic in Italy: A lesson for mental health prevention in the first severely hit European country. Psychol Trauma 2020;12:531-3. doi: $10.1037 /$ tra0000687m

3. Alon T, Kim M, Lagakos D, Van Vuren M. How should policy responses to the Covid-19 pandemic differ in the developing world?. Natl Bur Econ Res Working Paper No. 27273;2020.

4. Wang QQ, Xu R, Volkow ND. Increased risk of COVID-19 infection and mortality in people with mental disorders: analysis from electronic health records in the United States. World Psychiatry 2021;20:124-30. doi:10.1002/wps.20806.

5. Vibriyanti D. Kesehatan mental masyarakat: mengelola kecemasan di tengah pandemi Covid19. J Kependud Ed Khusus Demogr 2020;2902:6974.

6. Lee J, Lee HJ, Hong Y, Shin YW, Chung S, Park J. Risk perception, unhealthy behavior, and anxiety due to viral epidemic among healthcare workers: the relationships with depressive and insomnia symptoms during COVID-19. Front Psychiatry 2021;12:615387. doi: 10.3389/fpsyt.2021.615387.

7. Nivette A, Ribeaud D, Murray A, et al. Noncompliance with COVID-19-related public health measures among young adults in Switzerland: insights from a longitudinal cohort study. Soc Sci Med 2020;268:113370. doi: 10.1016/j. socscimed.2020.113370.

8. Usher K, Bhullar N, Jackson D. Life in the pandemic: social isolation and mental health. $\mathrm{J}$ Clin Nurs 2020;29:2756-7. doi: 10.1111/jocn.15290.

9. Choi EPH, Hui BPH, Wan EYF. Depression and anxiety in Hong Kong during COVID-19. Int J Environ Res Public Health 2020;17. doi: 10.3390/ ijerph17103740.

10. Gómez-Salgado J, Andrés-Villas M, DomínguezSalas S, Díaz-Milanés D, Ruiz-Frutos C. Related health factors of psychological distress during the COVID-19 pandemic in Spain. Int J Environ Res Public Health 2020;17. doi:10.3390/ ijerph17113947.

11. Li J, Liang W, Yuan B, Zeng G. Internalized stigmatization, social support, and individual mental health problems in the public health crisis. Int J Environ Res Public Health 2020;17:1-14. doi:10.3390/ijerph17124507.

12. Bonanno GA, Brewin CR, Kaniasty K, La Greca AM. Weighing the costs of disaster: Consequences, risks, and resilience in individuals, families, and communities. Psychol Sci Public Interes Suppl 2010;11:1-49. doi:10.1177/ 1529100610387086

13. Feijt M, de Kort Y, Bongers I, Bierbooms J, Westerink J, IJsselsteijn W. Mental health care goes online: practitioners' experiences of providing mental health care during the COVID19 pandemic. Cyberpsychol Behav Soc Netw 2020;23: 860-4. doi:10.1089/cyber.2020.0370.

14. Gadelha A, Fonseca L, Diniz E, Mendonca G, Malinowski F, Mari J. Schizophrenia and COVID19: risks and recommendations. Brazilian J Psychiatry 2020;42:236-8. doi:10.1590/1516-44462020-0010.

15. Greenberg N, Docherty M, Gnanapragasam S, Wessely S. Managing mental health challenges faced by healthcare workers during covid-19 pandemic. BMJ 2020;368:10-12. doi:10.1136/ bmj.m1211.

16. Vigo D, Patten S, Pajer K, et al. Mental health of communities during the COVID-19 pandemic. Can J Psychiatry 2020;65:681-7. doi:10.1177/ 0706743720926676.

17. Vasilj I, Herceg K, Covic I, et al. Determinants of the Covid-19 pandemic in the West Herzegovina Canton. Psychiatr Danub 2020;32:221-5. doi: 10.1001/jamanetworkopen.2020.14053.

18. Rettie H, Daniels J. Coping and tolerance of uncertainty: predictors and mediators of mental health during the Covid-19 pandemic. Am Psychol 2020. Advance online publication. doi: 10.1037/ amp0000710.

19. Alonzi S, La Torre A, Silverstein MW. The psychological impact of preexisting mental and physical health conditions during the COVID-19 paniemic. Psychol Trauma 2020;12:236-8. doi: 10.1037/tra0000840.

20. Poudel K, Subedi P. Impact of COVID-19 pandemic on socioeconomic and mental health aspects in Nepal. Int J Soc Psychiatry 2020;66:74875. doi:10.1177/0020764020942247.

21. Cullen W, Gulati G, Kelly BD. Mental health in the COVID-19 pandemic. QJM 2020;113:311-2. doi:10.1093/qjmed/hcaa110. 
22. Dania IA. Psychiatric aspects of long-term care. J Kes Masy Gizi 2019;1:27-37.

23. Giménez-Espert MDC, Prado-Gascó V, Soto-Rubio A. Psychosocial risks, work engagement, and job satisfaction of nurses during COVID-19 pandemic. Front Public Health 2020;8:1-10. doi:10.3389/fpubh.2020.566896.

24. Werner EA, Aloisio CE, Butler AD, et al. Addressing mental health in patients and providers during the COVID-19 pandemic. Semin Perinatol 2020;44:151279. doi:10.1016/ j.semperi.2020.151279.

25. Hubbard G, den Daas C, Johnston M, Dixon D. Sociodemographic and psychological risk factors for anxiety and depression: findings from the Covid-19 health and adherence research in Scotland on mental health (CHARIS-MH) crosssectional survey. Int J Behav Med 2021. doi: 10.1007/s12529-021-09967-z.

26. Thombs BD, Kwakkenbos L, Henry RS, et al. Changes in mental health symptoms from preCOVID-19 to COVID-19 among participants with systemic sclerosis from four countries: a Scleroderma Patient-centered Intervention Network (SPIN) cohort study. J Psychosom Res 2020;139. doi: 10.1016/j.jpsychores.2020.110262.

27. Thombs BD, Bonardi O, Rice DB, et al. Curating evidence on mental health during COVID-19: a living systematic review. J Psychosom Res 2020; 133: 110113. doi: 10.1016/j.jpsychores.2020.110113.

28. Spoorthy MS. Mental health problems faced by healthcare workers due to the COVID-19 pandemic-a review. Asian J Psychiatr 2020;51: 2018-21. doi: 10.1016/j.ajp.2020.102119.

29. Vindegaard N, Benros ME. COVID-19 pandemic and mental health consequences: Systematic review of the current evidence. Brain Behav Immun 2020;89:531-42. doi:10.1016/j.bbi.2020. 05.048 .

30. Lancet. Editorial: COVID-19: protecting healthcare workers. Lancet 2020;395:922. doi: 10.1016/ S0140-6736(20)30644-9.

31. Brenner MH, Bhugra D. Acceleration of anxiety, depression, and suicide: secondary effects of economic disruption related to COVID-19. Front Psychiatry 2020;11:592467. doi: 10.3389/fpsyt. 2020.592467.

32. Kang L, Li Y, Hu S, et al. The mental health of medical workers in Wuhan, China dealing with the 2019 novel coronavirus. Lancet Psychiatry 2020;7:14. doi:10.1016/S2215-0366(20)30047-X.

33. Cai H, Tu B, Ma J, et al. Psychological impact and coping strategies of frontline medical staff in Hunan between January and March 2020 during the outbreak of coronavirus disease 2019
(COVID) in Hubei, China. Med Sci Monit 2020;26: 1-16. doi:10.12659/MSM.924171.

34. Lee SM, Kang WS, Cho AR, Kim T, Park JK. Psychological impact of the 2015 MERS outbreak on hospital workers and quarantined hemodialysis patients. Compr Psychiatry 2018;87:123-7. doi: 10.1016/j.comppsych.2018. 10.003 .

35. Liang Y, Chen M, Zheng X, Liu J. Screening for Chinese medical staff mental health by SDS and SAS during the outbreak of COVID-19. J Psychosom Res 2020; 133:110102. doi: 10.1016/ j.jpsychores.2020.110102.

36. Xiao H, Zhang Y, Kong D, Li S, Yang N. The effects of social support on sleep quality of medical staff treating patients with Coronavirus disease 2019 ( COVID-19) in January and February 2020 in China. Med Sci Monit 2020;26:e923549-1-e-8. doi: 10.12659/MSM.923549.

37. Lai J, Ma S, Wang Y, et al. Factors associated with mental health outcomes among health care workers exposed to Coronavirus disease 2019. JAMA Netw open 2020;3: e203976. doi:10.1001/ jamanetworkopen.2020.397.6.

38. Mohindra R, Suri V, Bhalla A, Singh SM. Issues relevant to mental health promotion in frontline health care providers managing quarantined/ isolated COVID19 patients. Asian J Psychiatr 2020;51: 102084.. doi:10.1016/j.ajp.2020.102084.

39. Mahase E. Covid-19: Mental health consequences need urgent research, paper advises. BMJ 2020;369:m1515. doi: 10.1136/ bmj.m1515.

40. International Labour Organization. Managing work-related psychosocial risks during the COVID-19 pandemic. Geneva: International Labour Organization; 2020.

41. Smith K, Ostinelli E, Macdonald O, Cipriani A. COVID-19 and telepsychiatry: development of evidence-based guidance for clinicians. JMIR Ment Health 2020;7:e21108. doi: 10.2196/21108./

42. van Bavel JJ, Baicker K, Boggio PS, et al. Using social and behavioural science to support COVID19 pandemic response. Nat Hum Behav 2020;4: 460-71. doi:10.1038/s41562-020-0884-Z.

43. Zhang Y. Impact of the COVID-19 pandemic on mental health and quality of life among local residents in Liaoning province, China: a crosssectional study. Int J Environ Res Public Health 2020;17:2381. doi: 10.3390/ijerph17072381.

44. Zhang W, Wang K, Zhao W, Xue Q. Mental health and psychosocial problems of medical health workers during the COVID-19 epidemic in China. Psychother Psychosom 2020;89:242-50. https:// doi.org/10.1159/000507639. 
46. Tan W, Hao F, Mcintyre RS, et al. Brain, behavior, and immunity is returning to work during the COVID-19 pandemic stressful? A study on immediate mental health status and psychoneuroimmunity prevention measures of Chinese workforce. Brain Behav Immun 2020;87:84-92. doi:10.1016/j.bbi.2020.04.055.

47. Kusumawardani, Arine D, Luthfiyana, Ulya N. The mental health of medical workers during the covid19 pandemic: how do we manage it? J Kes Ling 2020;12.21-8. doi: 10.20473/jkl.v12i1si.2020.

48. Mann DM, Chen J, Chunara R, Testa P, Nov O. COVID-19 transforms health care through telemedicine: evidence from the field. J Am Med InformAssoc 2020;27:1132-5. doi: 10.1093/jamia/ ocaa072.

49. Kola L, Kohrt BA, Hanlon C, et al. COVID-19 mental health impact and responses in low-income and middle-income countries: reimagining global mental health. Lancet Psychiatry 2021;0366:1-16.

50. Naushad VA, Bierens JJLM, Nishan KP, et al. A systematic review of the impact of disaster on the mental health of medical responders. Prehosp Disaster Med 2019;34:632-43. doi: 10.1017/ S1049023X19004874.

51. Badrfam R, Zandifar A, Arbabi M. Mental health of medical workers in COVID-19 pandemic: restrictions and barriers. Hamadan Univ Med Sci 2020;20:e00481 doi:10.34172/jrhs.2020.16.

52. Maulik PK, Thornicroft G, Saxena S. Roadmap to strengthen global mental health systems to tackle the impact of the COVID 19 pandemic. Int J Ment Health Syst 2020;14:57. https://doi.org/10.1186/ s13033-020-00393-4.

53. Zalsman G, Stanley B, Szanto K, Clarke DE, Carli $\mathrm{V}$, Mehlum L. Suicide in the time of COVID-19: review and recommendations. Arch Suicide Res.2020;24:477-82. doi: 10.1080/13811118.2020. 1830242.

54. Hagger MS, Keech JJ, Hamilton K. Managing stress during the coronavirus disease 2019 pandemic and beyond: reappraisal and mindset approaches. Stress Heal 2020;36:396-401. doi: 10.1002/smi.2969.

55. World Health Organization. Mental health and psychosocial considerations during COVID-19 outbreak. Geneva: World Health Organization; 2020.

56. Donnelly R, Farina MP. How do state policies shape experiences of household income shocks and mental health during the COVID-19 pandemic? Soc Sci Med 2021;269:113-557. doi: 10.1016/ j.socscimed.2020.113557. 